\title{
Mixed and Hybrid Models of Public Service Delivery
}

Germà Bel, Trevor Brown and Mildred E. Warner

Editorial Overview for Special Issue on Mixed and Hybrid Models of Public Service Delivery

\section{International Public Management Journal}

17 (3), pp. 297-307, 2014

Germà Bel, Universitat de Barcelona (gbel@ub.edu $)^{1}$

Trevor Brown, The Ohio State University (brown.2296@osu.edu)

Mildred Warner, Cornell University (mew15@,cornell.edu)

\begin{abstract}
This symposium presents research from different contexts to improve our collective understanding of a variety of aspects of mixed forms of service delivery be they mixed contracting at the level of the market (which is more common in the US), or mixed management and ownership at the level of the firm (which is more common in Europe). The papers included in this special issue examine the factors that give rise to mixed forms of service delivery (e.g. economic and fiscal stress, regulatory flexibility, geography, management) and how these factors impact their design and operation. Papers also explore the performance of mixed forms of service delivery relative to more conventional arrangements like contracted or direct service delivery. The papers contribute to a better theoretical and conceptual understanding of mixed/hybrid forms of services delivery.
\end{abstract}

\footnotetext{
${ }^{1}$ Authorship is listed alphabetically. The three authors collaborated equally as a team in editing the symposium.
} 


\section{Mixed and Hybrid Models of Public Service Delivery}

\section{INTRODUCTION}

To date, the extant literature on service delivery has largely focused on the classic "make or buy" choice, the decision by governments to deliver public goods and services directly with government employees or through a contract with some other entity. This research has produced important findings. Factors explaining why local governments make in some cases and buy in others have been thoroughly analyzed, and a large set of empirical evidence is available in the literature (see e.g., Bel and Fageda, 2009). The literature has begun to examine the outcomes of these choices, particularly whether public or private production results in lower delivery costs (see e.g., Bel, Fageda and Warner 2010).

The results of the privatization of local services have been mixed. While there are notable examples of successful contracted service delivery, contracting services to private producers has not always produced the results expected by promoters. Research has identified a variety of potential explanatory factors for this mixed record: variable transaction costs in the management of direct and privatized service delivery (Brown and Potoski, 2003a, 2003b, 2005; Levin and Tadelis 2010; Hefetz and Warner 2012); instability in the use of contracting and direct service delivery (Warner and Hefetz 2012) combined with high costs of switching from one mode to another (Brown, Potoski, and Van Slyke, 2008); spatial differences in the markets of private providers (Hefetz, Warner and Vigoda-Gadot 2012; Joassart-Marcelli, P., and Musso, J. 2005); and the diminishment of competition over time for some goods and services (Bel and Costas 2006, Bel and Fageda 2011, Girth et al., 2012). The inquiry into service delivery choices has also suffered from a narrow focus on two idealized choices - pure public 
and pure private delivery - that do not necessarily reflect the actual practice of service delivery at different levels of government and in different contexts. In practice, there exist alternatives for local services reform different from exclusive privatization or direct service delivery (Warner and Hebdon 2001).

Several important delivery forms depart from the pure public-pure private delivery duality. Within the private and public dimension, an important alternative frequently used in the US is mixed delivery. Mixed production in the US happens at the level of the market where local governments mix delivery by using both private contracts and public production for the same service. Miranda and Lerner (1995) noted mixed forms of service delivery in 1982 data on US local government service delivery practices collected by the International City/County Management Association (ICMA). Based on subsequent surveys by the ICMA, the use of mixed delivery increased from 1992 to 2002 (Warner and Hefetz 2008). There are a variety of potential explanations for the steady increase in the use of mixed alternatives. Mixed delivery can create competition between public and private providers in the local market thus providing more complete information on the nature and cost of service delivery. This can reduce transactions costs and ensure government capacity to assume responsibility for service delivery in the case of contract failure (Miranda and Lerner 1995; Warner and Hefetz 2008; Brown, Potoski, and Van Slyke 2006). Mixed delivery is also associated with lower rates of privatization reversals and higher rates of new contracting out (Hefetz and Warner 2007; Warner and Hefetz 2012). Mixed delivery allows local governments to benchmark costs and production processes (Miranda and Lerner 1995; Brown, Potoski and Van Slyke, 2008; Warner and Hefetz 2008) and helps to maintain competition in the local service market through competitive bidding between public and private crews (Hefetz, Warner and Vigoda-Gadot 2014; Girth et al. 2012; Albalate, Bel 
and Calzada 2012). Mixed service delivery can also potentially lower the costs of switching between pure public and pure private modes (Brown, Potoski, and Van Slyke, 2008).

Mixed delivery is not as frequent in Europe as it is in the US (Warner and Bel 2008). Two other organizational forms are more common in many European countries (OECD 2000a, 2000b): mixed public-private firms and government owned firms. Mixed public-private ownership of firms is an important production form in Europe (Cruz et al. 2014). In mixed public-private firms (mixed firms hereafter) ownership is divided between the government and private partners. The private partner tends to be a large firm with an established position in the service delivery market, and is usually in charge of managing the day-to-day operations. On the other side, governments can retain controlling stakes or minority stakes. In any case, by doing so, governments engage in long term contracts with private partners through joint ventures, and combine government objectives with profit maximization in the operation of the firm.

In government owned firms (public firms hereafter) the government retains ultimate control over the organization of the delivery of the service. Moreover, public firms are organized under private commercial law rules. Because of this, the autonomy of managers is much greater and, particularly, managers have much more flexibility regarding important factors such as labor organization and purchases of inputs (Warner and Bel 2008; Swarts and Warner 2014).

Outside the public and private dimension, other important production organizational forms exist, such as Interlocal/Intermunicipal cooperation and delivery by non-for-profit organizations. Inter-municipal cooperation is one of the features of contemporary local government management (Zeemering, 2008), and it has been growing, especially in the US (Hefetz, Warner and Vigoda-Gadot 2012). It is seen as an 
alternative to consolidation (Thurmaier and Wood 2004); instead of focusing on amalgamating or consolidating governments, the focus here lies on "functional consolidation" of services through shared delivery arrangements (Holzer and Fry 2011). The potential of sharing services as an alternative metropolitan regional governance reform was envisaged half a century ago by Ostrom, Tiebout and Warren (1961, p. 836), when they suggested that small municipalities could make use of special arrangements to act jointly to provide services when the municipal boundary is suboptimal. Even if higher tier governments provide incentives or a legal framework for cooperation, cooperation among local governments is characterized by being voluntary and not compulsory (Feiock, 2008). Cooperation is an important means to address transaction costs and is an important alternative in markets with low competition (Bel, Fageda and Mur 2014; Hefetz and Warner 2012; Girth et al. 2012).

Responding to the increasing interest in the scholarly research in Public Administration, Political Science, and Economics in delivery choices which move beyond the duality of pure public-pure private, the research unit Government and Markets and the Chair Pasqual Maragall on Economics and Territory (both at University of Barcelona, Spain) and the International Public Management Journal sponsored the workshop "Neither Public nor Private: Mixed Forms of Service Delivery around the Globe", in May 2012 at the School of Economics at the University of Barcelona.

The symposium aimed to build from this foundational knowledge but push research in new directions to better understand the creation, operation, and performance of the wide range of mixed forms of service delivery, which combine public, private, nonprofit, and/or community resources. These mixed forms include: Hybrid Organizational Forms (Public corporations, state owned enterprises, mixed public- 
private firms and public-private/nonprofit partnerships) and Mixed Contracting (with private, non profit or other governments), and Co-production across jurisdictions or between government. We focus on hybrid organizational forms and mixed

public/private contracting in this special issue. The purpose of the symposium was to draw on research in different contexts to improve our collective understanding of a variety of aspects of mixed forms of service delivery. We were particularly interested in examining the factors that give rise to mixed forms of service delivery (e.g. economic and fiscal stress, regulatory flexibility, geography, management, transaction costs) and how these factors impact their design and operation. We were also interested in explaining the performance of mixed forms of service delivery relative to more conventional arrangements like contracted or direct service delivery.

\section{CONTRIBUTIONS ON MIXED AND HYBRID MODELS}

In "Beyond pure public and pure private management models: Partial privatization in the European Airport Industry," Daniel Albalate, Germà Bel and Xavier Fageda examine the motivations that influence the degree of private participation in the European airport sector. They first analyze the choice of mixed public-private companies instead of pure management models. After that, they focus on the degree of private participation taking into account the percentage of private ownership of the firm. While previous studies have analyzed mixed delivery modes in the US or the determinants of cooperation, this paper focuses on another strategy to go beyond the dilemma between pure delivery forms (public or private): the partial privatization of public services by means of mixed public-private companies. 
They draw data from a sample of the 100 largest airports in Europe to estimate a multivariate equation using a generalized linear model with fractional response variables. The analysis considers as explanatory variables several airport characteristics (amount and type of traffic, competition from nearby airports, airline's attributes) along with fiscal and political factors taking into account that both private and public partners share interests in the association through mixed public-private governance models.

Based on the empirical analysis, Albalate, Bel and Fageda find that the degree of privatization of airports seems to be a pragmatic choice of governments. The variable of ideology is not relevant, while variables related with the economic interests of private investors or governments are clearly positive and statistically significant. Furthermore, they find that specific characteristics of airports like size, congestion, competition and type of dominant airlines have influence on the involvement of private partners in these facilities, by means of mixed or fully privatized firms. These characteristics affect the expectations of private investors or limit the interest of governments for fear of losing their control. Furthermore, evidence is obtained that integrated management models decrease private involvement. Finally, this study confirms that the share of private investment in airport management firms is higher in the United Kingdom than in countries of continental Europe.

In "Understanding mixed forms of refuse collection, privatization and its reverse in the Netherlands" Raymond Gradus, Elbert Dijkgraaf and Mattheus Wassenaar analyze patterns over time in changes in the Dutch modes of production for refuse collection, ranging from direct to contracted production: in-house collection, outsourcing to neighboring municipalities, municipal cooperation, provision by municipal, and private enterprises. 
The authors find that the number of municipalities using mixed forms such as municipal enterprises increased in the Netherlands between 1998 and 2010, as the use of other forms declined. Municipal co-operation only decreased slightly. The figures indicate that when dealing with increasing returns to scale, municipal enterprises and municipal cooperation can be viable alternatives for privatization. In approximately half of Dutch municipalities, the mode of production was stable between 1998 and 2010. In the other municipalities, 421 shifts took place, with two-thirds being towards outside production and one-third towards inside production. Looking at the shifts, reverse privatization was favored almost as much as privatization. When distinguishing between two periods (1998-2004 and 2005-10), they found that reverse privatization became more important in the later period. This is similar to results found in the US (Hefetz and Warner 2007, Warner and Hefetz 2012). The rise in mixed forms as a preferred choice for Dutch municipalities raises the question of whether contracting out to private waste collectors is beneficial over time.

Based on a logit model, Gradus, Dijkgraaf and Wassenaar find some evidence of an ideological motivation for changing the mode of production. More conservative political parties are in favor of moving service delivery towards market provision, while more social democratic parties tend to oppose the move. They do not find an effect from unemployment, so there is no evidence of an interest group effect. For income, negative effects are found in some cases, implying that richer municipalities are less likely to change. Evidence of scale effects is found for changes to the market and privatization. The results imply that larger municipalities have lower chances of shifting to the market and privatization. Some evidence is also found for a negative effect of higher population density. The estimations in this article seem to be robust when distinguishing between 
periods. Interestingly, the effect of income on privatization disappears, which gives some indication that the efficiency motive has become less relevant to decision making.

In "What drives the partnership decision? Examining structural factors influencing public-private partnerships for municipal wireless broadband," Amanda Girth assesses the determinants of public-private partnerships for an emerging service area by focusing on the structural attributes of US local governments. Although there is much written about the nature of public-private partnerships, there has been little scholarly attention paid to the partnership decision - that is, why governments pursue partnerships in lieu of public provisioning. She draws from the robust body of research on the "make or buy" decision in government contracting to help answer this question.

Girth uses primary data to analyze the partnership decision for municipal wireless broadband networks, a relatively new service offering in the US. She finds determinants of public-private partnerships behave in some ways like government contracting decisions. First, municipalities with political-administrative autonomy are more likely to enter partnerships. That is, municipalities with council-manager form of government are more likely to partner with private firms to implement municipal wireless broadband. Prior research shows that city managers are more likely to engage in alternative service delivery and tend to be early innovators. Yet she also ties this finding to risk and continuity, suggesting that private partners might be more attracted to municipalities with greater administrative autonomy and executive continuity. Similarly, she finds that the economic strength of the municipality is a predictor of partnerships. In short, the ability to attract a private partner hinges on the desirability of the community. As policymakers increasingly seek public-private partnerships as alternatives to public provisioning, this work sheds light on the characteristics of communities likely to reap the benefits of partnership. 
While Girth's study provides key insights into the partnership decision for local governments, the policy area within which the work is situated has significant implications for researchers and policymakers. She demonstrates clear equity rationales to support government involvement in wireless broadband access. Underserved areas - urban and rural areas where the costs (infrastructure development and/or cost of service) have slowed private investment - lag notably behind in broadband access and adoption. Her review of the policy landscape shows that this disparity has real economic impact on underserved communities.

In "Concurrent sourcing in the public sector: A strategy to manage contracting risk," Amir Hefetz, Mildred Warner and Eran Vigoda-Gadot compare the twin dynamics of mixed versus total contracting strategies and the choice of contract agent private for profit or other government. Drawing from the private sector literature on concurrent sourcing, they show how mixed delivery can help governments maximize market complementarities between local governments and their contractors. These can lead to reduction in contracting risk. They also give attention to the difference in contracting agent - private market agents or public markets of other local governments. They employ a national sample of 1474 US local governments and their contracting decisions across the full range of 67 services that local governments provide. While $38 \%$ of all private contracts are mixed, only $13 \%$ of contracts to other governments involve mixed delivery. In addition, they use a set of transaction cost measures that address asset specificity, contract management difficulty, citizen interest in service delivery and level of competition in the market (Hefetz and Warner 2012). They also control for location in the urban hierarchy, managerial learning, labor opposition and population and income. They find that competition is the primary driver and is positively associated with the choice of mixed delivery with for profit agents, and 
negatively associated with the decision to totally contract out with other governments. Private contracts require careful market management, whereas contracts to public agents are a means of managing risks in low competition situations. Larger cities are more likely to mix delivery, whereas smaller cities are more likely to use total contracts to other governments. Only suburbs are more likely to use total contracting out with private agents. This may reflect the more competitive urban environment in which suburbs are located. Higher levels of overall citizen interest, also lead to more mixed delivery, among both public and private agents.

Heftez, Warner and Vigoda-Gadot have opened up a new line of research that unpacks the relationship between choice of a mixed or total contracting out strategy and the importance of contracting agent. They look at the mixed delivery alternative as a means for public organizations to engage with markets at lower risk. In their empirical analysis they argue, local government should be modeled as a multi-product firm, where balance across multiple objectives and across services is reflected in the aggregate contracting decision portfolio. They also offer fresh theoretical insights that link public administration to private management theory - showing the benefits of a public sector analysis in offering a broader perspective on the nature of concurrent sourcing.

\section{FUTURE RESEARCH ON MIXED/HYBRID FORMS OF SERVICE DELIVERY}

As the papers in this special issue show, there is a wide array of issues that need to be addressed by future research as the focus shifts from analysis of why governments choose to make or buy, to a focus on why they chose to make and buy, either through mixed market contracting or new hybrid forms of organization or networks. Williamson (1999) argued that a mixed/hybrid position could occur, especially in the public sector where issues of failsafe delivery and broader public objectives must be 
coupled with concerns for efficiency. Separating the mixed phenomenon into these two broad arenas, mixed market contracting or mixed firms, can facilitate our exploration of future research challenges.

\section{Mixed Contracting}

Mixed contracting is much more common in the US than Europe. Heftez, Warner and Vigoda-Gadot (2014) link analysis of this phenomenon in the public sector to scholarship in the private sector on concurrent sourcing. They argue a mixed, make and buy strategy is a means to manage risks due to information asymmetries and lack of competition. But they also point to the positive potential for market complementarities between the public and private actors. Articulating the nature of these market complementarities would be fruitful arena for future research. Complementarities may be found in smoother implementation of new technology; information and knowledge exchange; and better accuracy in identifying user preferences. These complementarities may differ between public and private contracting partners and future research should look more closely at the nature of partner (and the goals and expertise that partner brings) and the need for a mixed strategy. Indeed, Heftez, Warner and Vigoda-Gadot (2014) find that mixed strategies are uncommon when contracting with other municipalities. Intermunicipal contracting may not require a mixed strategy because the goal alignment and accountability structures are more common across public partners. Future research should give more attention to the nature of inter-municipal cooperation, its drivers and outcomes, as it appears to provide an alternative to mixed delivery. 


\section{Mixed Firms}

This model is much more common in Europe and was the subject of a special issue in the Annals of Public and Cooperative Economics also published this year (Cruz et al. 2014). The shift from contractual arrangements to shared ownership raises the question of whether relationships, inside the firm, are better ways to ensure public objectives are met, than arm's length contracting. While these institutionalized arrangements certainly move us beyond the challenges of relational contracting, they raise challenges of their own. Vining, Boardman and Moore (2014) have pointed out some of the gaps in the emerging theory on mixed firms. They argue for the development of a better theoretical and normative framework - especially as regards social objectives and power within the firm. Peters, Pierre and Røiseland (2014) raise similar concerns about whether mixed firms will shift objectives from public to more private concerns. As Albalate, Bel and Fageda (2014) show in their study of airports, the extent of private versus public control and what that means for market position, strategic action and potential market or political interference in service delivery are important avenues for future research. Baker and Freestone (2012) have shown how the strength of private actors in these mixed arrangements can undermine public planning processes.

Closer to pure public delivery are the municipal companies that Gradus, Dijkgraaf and Wassenaar (2014) show are on the rise in the Netherlands. These are also quite common in Italy and Spain. Research should focus on the institutional contexts that give rise to these organizational forms. In Italy these may be a response to EU objectives to liberalize, a form of partial privatization (Asquer 2014). Municipal companies take the enterprise model of budgeting one step further from direct municipal control. Distance from municipal control may have positive and negative implications 
for accountability and efficiency.

\section{Causal Factors}

As noted in the introduction, the literature on the classic "make or buy" decision has identified an array of causal factors that explain the choice. Future research should continue to assess whether the same factors that explain the variable use of direct or contracted service delivery also help explain the full range of different service delivery modes. A principal advantage of this symposium is that it sheds light on a phenomenon that occurs across contexts (i.e., Europe and the United States) and products and markets (i.e., wireless provision, airport management, and refuse collection and other local services). Future research should more systematically assess whether spatial factors like the urban, suburban, rural distinctions (e.g., Hefetz and Warner, 2003) that characterize many industrialized nations are drivers of mode choice across the globe. Similarly, characteristics of different goods and services - such as the ease of specifying desired attributes and outcomes - should be examined more closely to see if patterns emerge across the range of mode choices (e.g., Brown, Potoski, and Van Slyke, 2013; Hefetz and Warner 2012).

Whether mixing at the level of the firm or the market, papers in this special issue have shown that exploring these new hybrid models is an important and understudied arena for future contracting research. These forms are a response to contracting failures relating to information asymmetries, lack of market competition, and need for greater oversight and control. But these forms are also an opportunity to take advantage of complementarities in finance, expertise and economies of scale. How these mixed delivery models balance between market complementarities and market failures will be critical in understanding the contribution and importance of this new reform. 


\section{REFERENCES}

Albalate, D., G. Bel and J. Calzada, 2012, "Governance and regulation of urban bus transportation: using partial privatization to achieve the best of two worlds," Regulation \& Governance, 6(1), 83-100.

Albalate, D., G. Bel and X. Fageda. 2014. "Beyond pure public and pure private management models: Partial privatization in the European Airport Industry." International Public Management Journal (this issue)

Asquer A., 2014. "Explaining partial privatization of public service provision: the emergence of mixed ownership water firms in Italy (1994-2009)," Annals of Public and Cooperative Economics, 85(1): 11-30.

Baker, D. and R. Freestone, 2012. "Land Use Planning for Privatized Airports," Journal of the American Planning Association, 78(3): 328-341.

Bel, G. and A. Costas. 2006. "Do public sector reforms get rusty?: Local privatization in Spain.” Journal of Policy Reform 9(1): 1-24.

Bel, G. and X. Fageda. 2009. "Factors explaining local privatization: a meta-regression analysis." Public Choice 139(1/2): 105-119.

Bel, G. and X. Fageda. 2011. "Big Guys Eat Big Cakes: Firm Size and Contracting In Urban and Rural Areas.” International Public Management Journal 14(1): 4-26.

Bel, G., X. Fageda and M. Mur. 2014. "Does Cooperation Reduce Service Delivery Costs? Evidence from Residential Solid Waste Services." Journal of Public Administration Research and Theory 24 (1), 85-107.

Bel, G., X. Fageda and M.E. Warner. 2010. "Is Private Production of Public Services Cheaper than Public Production? A meta-regression analysis of solid waste and water services." Journal of Policy Analysis and Management 29(3): 553-577. 
Brown, T. L. and M. Potoski. 2003a. "Transaction costs and institutional explanations for government service production decisions." Journal of Public Administration Research and Theory 13 (4): 441-468.

Brown, T. L. and M. Potoski. 2003b. "Managing contract performance: A transaction cost approach.” Journal of Policy Analysis and Management 22 (2): 275-297.

Brown, T. L. and M. Potoski. 2005. "Transaction Costs and Contracting: The Practitioner Perspective.” Public Performance and Management Review 28(3): $326-351$.

Brown, T., M. Potoski and D. Van Slyke. 2006. "Managing Public Service Contracts: Aligning Values, Institutions, and Markets.” Public Administration Review 66 (3): $323-331$.

Brown , T. , M. Potoski and D. Van Slyke. 2008. "Changing Modes of Service Delivery: Costs and Constraints," Environment and Planning C: Government and Policy, 26(1), 127-143.

Brown, T. , M. Potoski and D. Van Slyke. 2013. Complex Contracting: Government Contract Contracting in the Wake of the U.S. Coast Guard's Deepwater Program. Cambridge, UK: Cambridge University Press.

Cruz, N.F., R.C. Marques, A. Marra and C. Pozzi 2014. "Local Mixed Companies: The Theory and Practice in an International Perspective," Annals of Public and Cooperative Economics 85(1): 1-10.

Feiock, Richard C. 2008. Institutional Collective Action and Local Government Collaboration. In Lisa B. Bingham and Rosemary O'Leary, eds., Big Ideas in Collaborative Public Management, pp. 195-210. New York: M.E. Sharpe. 
Girth, A. 2014. "What drives the partnership decision? Examining structural factors influencing public-private partnerships for municipal wireless broadband," International Public Management Journal (this issue).

Girth, A., A. Hefetz, J. Johnston and M.E. Warner 2012. “Outsourcing Public Service Delivery: Management Responses in Noncompetitive Markets," Public Administration Review, 72(6): 887-900.

Gradus, R. E. Dijkgraaf and M. Wassenaar. 2014. "Understanding mixed forms of refuse collection, privatization and its reverse in the Netherlands." International Public Management Journal (this issue).

Hefetz, A. and M. E. Warner. 2007. "Beyond the Market vs. Planning Dichotomy: Understanding Privatisation and its Reverse in US Cities," Local Government Studies, 33(4): 555-572.

Hefetz, A. and M. E. Warner. 2012. "Contracting or Public Delivery? The importance of service, market and management characteristics," Journal of Public Administration Research and Theory, 22(2): 289-317.

Hefetz, A., M. E. Warner and E. Vigoda-Gadot. 2012. "Privatization and InterMunicipal Contracting: US Local Government Experience 1992-2007." Environment and Planning C: Government and Policy 30(4): 675-692.

Hefetz, A., M. E. Warner and E. Vigoda-Gadot. 2014. "Concurrent sourcing in the public sector: A strategy to manage contracting risk," International Public Management Journal (this issue).

Holzer, M. and J. Fry. 2011. Shared services and municipal consolidation. A critical analysis. Public Technology Institute, Alexandria (VA). 
Joassart-Marcelli, P., \& Musso, J. (2005). Municipal service provision choices within a metropolitan area. Urban Affairs Review, 40(4), 492-519.

Levin, J., and Tadelis, S. (2010). "Contracting for government services: Theory and evidence from U.S. cities.” Journal of Industrial Economics 58(3): 508-541.

Miranda , R. and A. Lerner. 1995. "Bureaucracy, Organizational Redundancy, and the Privatization of Public Services," Public Administration Review 55(2): 193- 200.

OECD. 2000a. Competition in Local Services: Solid Waste Management. Paris: Organization for Economic Cooperation and Development.

OECD. 2000b, Global Trends in Urban Water Supply and Waste Water Financing and Management: Changing Roles for the Public and Private Sectors. Paris: Organization for Economic Cooperation and Development.

Ostrom, V., C.M. Tiebout, and R. Warren 1961. The organization of government in metropolitan areas: A theoretical inquiry. American Political Science Review 55(4): 831-842.

Peters, B.G., J. Pierre and A. Røiseland A., 2014, "Financial gains and value loss? The impacts of local mixed companies," Annals of Public and Cooperative Economics, 85(1): 87-102.

Swarts, D. and M.E. Warner 2014. "Hybrid Firms and Transit Delivery: The Case of Berlin," Annals of Public and Cooperative Economics, 85(1): 127-146.

Thurmaier, K. and C. Wood. 2004. Interlocal Agreements as an Alternative to Consolidation. In Jered B. Carr and Richard Feiock, eds. City-County Consolidation and Its Alternatives. Reshaping the Local Government Landscape, pp. 113-130. M.E. Sharpe, New York. 
Vining, A., A. Boardman and M. Moore. 2014. "The theory and evidence pertaining to local government mixed enterprises," Annals of Public and Cooperative Economics, 85(1): 53-86.

Warner, M. E. and G. Bel. 2008."Competition or monopoly? Comparing privatization of local public services in the US and Spain." Public Administration 86(3): 723-735.

Warner, M. E. and R. Hebdon. 2001. "Local government restructuring: privatization and its alternatives." Journal of Policy Analysis and Management 20(2): 315-336.

Warner, M.E. and A. Hefetz. 2003. "Rural-Urban Differences in Privatization: Limits to the Competitive State," Environment and Planning C: Government and Policy, 21(5): 703-718.

Warner, M. E. and A. Hefetz. 2008. "Managing Markets for Public Service: The Role of Mixed Public/Private Delivery of City Services." Public Administration Review 68(1): 155-166.

Warner, M. E. and A. Hefetz. 2012. "In-Sourcing and Outsourcing: The Dynamics of Privatization among US Municipalities 2002-2007." Journal of the American Planning Association 78(3): 313-327.

Williamson, O. E. 1999. "Public and Private Bureaucracies: A Transaction Cost Economics Perspective." The Journal of Law, Economics, \& Organization 15(1): $306-342$.

Zeemering, Eric. 2008. Governing interlocal cooperation: City council interests and the implications for public management. Public Administration Review 68(4): 731741. 